\title{
Impaired Elastin Fiber Assembly Related to Reduced 67-kD Elastin-binding Protein in Fetal Lamb Ductus Arteriosus and in Cultured Aortic Smooth Muscle Cells Treated with Chondroitin Sulfate
}

\author{
Aleksander Hinek, ${ }^{*}$ Robert P. Mecham, ${ }^{*}$ Fred Keeley, ${ }^{*}$ and Marlene Rabinovitch* \\ *Departments of Pathology, Biochemistry, and Pediatrics, University of Toronto, and the Division of Cardiovascular Research, \\ Research Institute, The Hospital for Sick Children, Toronto, Ontario M5G1X8, Canada; and ${ }^{\ddagger}$ Department of \\ Cell Biology and Physiology, Washington University School of Medicine, St. Louis, Missouri 63110
}

\begin{abstract}
In the fetal ductus arteriosus (DA) disruption in the assembly of elastin fibers is associated with intimal thickening and we previously reported that fetal lamb DA smooth muscle cells incubated with endothelial conditioned medium produce twofold more chondroitin sulfate (CS) compared with aorta (Ao) cells (Boudreau, N., and M. Rabinovitch. 1991. Lab. Invest. 64:187-199). We hypothesized that CS or dermatan sulfate (DS), both $\mathrm{N}$-acetylgalactosamine glycosaminoglycans (GAGs), may be similar to free galactosugars in causing release of the 67-kD elastin binding protein (EBP) from the smooth muscle cell surfaces and impaired elastin fiber assembly. Using immunohistochemistry, immunoelectron microscopy, and western immunoblot we demonstrated a reduction in the $67-\mathrm{kD}$ EBP in fetal lamb DA smooth muscle in tissue and in cultured cells. Also, reduced EBP was observed in fetal lamb and neonatal rat Ao smooth muscle cells incubated with $\boldsymbol{N}$-acetylgalactosamine GAGs, CS, and DS, but not with $\boldsymbol{N}$-acetylglucosamine containing GAGs, heparan sulfate (HS), or hyaluronan. Reduction in EBP was related to shedding from cell surfaces into the conditioned medium. This was associated with impaired elastin fiber assembly in cultured cells, assessed both morphologically and by a relative increase in tropoelastin and decrease in desmosines. The EBP extracted from smooth muscle cell membranes binds to an elastin affinity gel and can be eluted from it with CS but not with HS. Moreover, the amount of EBP extractable from smooth muscle cell membranes correlated with the morphologic assessment. We propose that increased CS or DS, may impair assembly of newly synthesized elastin in the media of the ductus arteriosus associated with the development of intimal thickening. (J. Clin. Invest. 1991. 88:2083-2094.) Key words: glycosaminoglycans • extracellular matrix • intimal thickening • vascular disease
\end{abstract}

This study was presented in part at the 74th Annual Meeting of the Federation of American Societies for Experimental Biology, Washington, DC, April 1990, and was published in abstract form (1990. FASEB [Fed. Am. Soc. Exp. Biol.] J. 4:905A. [Abstr.]).

Address correspondence to Marlene Rabinovitch, M.D., Division of Cardiovascular Research, The Hospital for Sick Children, 555 University Ave., Toronto, Ontario M5G1X8 Canada.

Received for publication 15 February 1991 and in revised form 08 July 1991.

J. Clin. Invest.

(C) The American Society for Clinical Investigation, Inc. $0021-9738 / 91 / 12 / 2083 / 12 \$ 2.00$

Volume 88, December 1991, 2083-2094

\section{Introduction}

The mechanism responsible for assembly of elastin fibers in blood vessels and other organs is not known. It has been proposed that the soluble precursor tropoelastin is secreted from cells and finds its way through the extracellular space to the growing elastin fiber where it interacts with glycoprotein microfibrils and becomes oriented in the proper alignment for cross-linking (see reviews, 1, 2). Previous studies (3-6) suggest that the assembly process is mediated at the cell surface by an elastin-binding complex. This complex has been isolated from elastin-producing cells and consists of three proteins. Two integral membrane proteins (55 and $61 \mathrm{kD}$ ) form a transmembrane link between the extracellular compartment and the cytoskeleton. The third subunit is a 'detachable' $67-\mathrm{kD}$ elastinbinding protein (EBP) 1 that also has galacto-lectin properties. It binds the hydrophobic VGVAPG sequence in elastin, the cell membrane, and galactosugars via three separate sites. Binding of galactosugars to the lectin site of the 67-kD EBP lowers its affinity for both tropoelastin and for the cell binding site, resulting in the release of bound elastin and the dissociation of the $67-\mathrm{kD}$ subunit from the cell membrane.

Galactosugar-containing microfibrillar glycoproteins may therefore be involved in the coordinated release of tropoelastin from the $67-\mathrm{kD}$ binding protein on the cell membrane to the growing elastin fiber. An excess of galactose-containing components of the extracellular matrix, e.g., glycoproteins, glycosaminoglycans, or galactolipids may, however, impair elastin assembly by causing premature release of tropoelastin and the elastin-binding protein from the cell surface. In previous reports we have in fact shown impaired formation of mature elastin fibers in cultured or transplanted elastin-producing cells treated with agarose (7) or following the addition of excess free nonsulfated galactosugars such as lactose, galactose, or galactosamine (3).

The ductus arteriosus (DA), an embryologic derivative of the sixth aortic arch, located between the pulmonary artery and the aorta, is a vessel in which there is impaired assembly of elastin fibers $(8,9)$. An increase in chondroitin sulfate (CS), an $\mathrm{N}$-acetylgalactosamine containing GAG has been described in the media and neointima of the DA (10), and in DA smooth muscle cells in vitro (11). We speculated that increased CS may lead to premature release of the EBP from DA smooth muscle cells and this may underlie the impaired elastin assembly ob-

1. Abbreviations used in this paper: $\mathrm{CS}$, chondroitin sulfate; DA, ductus arteriosis; DS, dermatan sulfate; EBP, elastin-binding protein, GAGs, glycosaminoglycans; GAM, goat anti-mouse; GAR, goat antirabbit; HA, hyaluronan; HRP, horseradish peroxidase; HS, heparan sulfate. 
served. In association with impaired elastin assembly in the media of the DA vessel wall, there is smooth muscle cell migration into the subendothelium and proliferation leading to the formation of intimal cushions. These structures are essential for the DA to close when it constricts in the postnatal period (12-14). Intimal cushions have some features which resemble intimal thickening associated with atherosclerosis and advanced pulmonary vascular disease and impaired assembly of elastin is a feature of both systemic (15) and pulmonary hypertension (16, and Todorovich-Hunter, L., H. Dodo, L. McCready, F. W. Keeley, and M. Rabinovitch, submitted for publication). Moreover, increased galactosamine containing glycosaminoglycans (GAGs), CS, and dermatan sulfate (DS) are observed in wounded vessels (17-19) and in atherosclerosis (20-27). The relationship between altered vascular elastin assembly and production of galactosamine containing GAGs has not, however, been established particularly in the setting of intimal thickening.

In this study, the amount of $67-\mathrm{kD}$ EBP was compared in fetal lamb DA and Ao smooth muscle cells and tissue by immunohistochemistry and immunoelectron microscopy. The morphologic appearance was correlated with the amount of EBP extractable from smooth muscle cells. We tested the hypothesis in fetal lamb and in neonatal rat Ao smooth muscle cells, that a reduction EBP and impaired elastin assembly can result from excess $N$-acetylgalactosamine containing GAGs, e.g., CS and DS compared with $N$-acetyl-glucosamine containing GAGs (HA) and (HS). We then compared CS with HS in its ability to elute the 67-kD EBP directly from an elastin affinity column. We also assessed whether the effect of the GAGs on elastin fiber assembly influenced tropoelastin and protein synthesis.

\section{Methods}

Materials. Affigel-10 for the preparation of affinity columns was purchased from Bio-Rad Laboratories, Inc. (Richmond, CA). Species and type-specific secondary antibodies, goat anti-rabbit (GAR) and goat anti-mouse (GAM), conjugated with gold particles for EM-immunolocalization were purchased from Janssen Life Science Products (Piscataway, NJ). Horseradish peroxidase (HRP)-conjugated antibodies used in western immunoblotting were from Boehringer Mannheim Biochemicals (Indianapolis, IN). Fluorescein (FITC) or rhodamine (RITC) conjugated GAM and GAR secondary antibodies were from ICN Immuno Biologicals (Lisle, IL). Peroxidase-antiperoxidase staining kit came from Dako (Santa Barbara, CA). We purchased $\left[{ }^{3} \mathrm{H}\right]-$ leucine from New England Nuclear (Boston, MA). Collagenase type Ia, human plasma fibronectin, chondroitin sulfate type A from bovine trachea, chondroitin sulfate type B (dermatan sulfate) from bovine intestinal mucosa, heparan sulfate from bovine kidney, hyaluronan from bovine vitreous humor, lactose, octa-beta glucoside (OBG), dithiotreithol (DTT), guanidine, and other reagent grade chemicals were purchased from Sigma Chemical Co. (St. Louis, MO). Medium 199, PBS, HBSS, FBS, and other tissue culture reagents were from Gibco (Grand Island, NY). Kappa-elastin, insoluble elastin $400-\mu \mathrm{m}$ mesh and tropoelastin standards were from Elastin Products (Pacific, MO). Desmosine antibody, desmosine standard, and $\left.{ }^{125} \mathrm{I}\right]$ desmosine were gifts from Dr. B. Starcher, University of Texas, Tyler, TX.

Cell cultures. Smooth muscle cells were harvested from the Ao and DA of 138-d gestation fetal Rabouillet lambs (term $=145$ d) by a protocol previously described (28). The timepoint chosen was concurrent with normal elastin fiber assembly in the Ao and disruption in elastin fiber assembly associated with the formation of intimal cushions in the DA $(9,11,28)$. Smooth muscle cells were grown from explants of the media as described (29) or were isolated after collagenase digestion (30). The cultured cells were similar morphologically using either technique, and were characterized as smooth muscle using a monoclonal antibody specific to smooth muscle actin (31). Also, no differences were seen in the following studies when comparing cells grown from explants or isolated after collagenase digestion. To determine whether features observed in fetal lamb Ao smooth muscle cells might be similar in other species, selected studies were also carried out with newborn rat Ao cells obtained after collagenase digestion. All cultures were maintained in medium 199 supplemented with $20 \mathrm{mM}$ Hepes, $1 \%$ antibiotics/antimycotics and $10 \%$ FBS, and all experiments were performed on first and second passage cells only. No differences were noted between first and second passage cells. In studies relating the distribution of the 67-kD EBP to elastin fiber assembly, Ao or DA cells were cultured in the same medium with and without exogenous GAGs added. These included chondroitin sulfate (CS), dermatan sulfate (DS), heparan sulfate (HS), and hyaluronan (HA) each in a concentration of $200 \mu \mathrm{g} / \mathrm{ml}$. Changes in the distribution of the $67-\mathrm{kD}$ protein were assessed $24 \mathrm{~h}$ after cell attachment, and at $7 \mathrm{~d}$ incubation at confluence. The latter timepoint was used to evaluate elastin fiber assembly. All experiments were repeated at least three times with cells from three different lambs or rats.

Measurement of tropoelastin, total protein, and desmosines. Total protein and tropoelastin synthesis were measured in triplicate from confluent 25 -ml flasks ( $\sim 2 \times 10^{6}$ smooth muscle cells) on days $1,2,3$, 5 , and 7 in untreated cultures or following addition of CS, DS, HS, or HA as previously described. Values of tropoelastin were expressed as ( $\mathrm{ng} / 10^{6}$ cells), the mean \pm SD obtained from three different experiments (nine samples). Protein synthesis (cpm/106 cells) was monitored at each timepoint under each condition and triplicate measurements from two different experiments were expressed as mean $\pm \mathrm{SD}$.

Soluble elastin (tropoelastin) in media and cell layer extracts was quantified separately by the direct-binding ELISA method (32) using rabbit monospecific antiserum to bovine tropoelastin. The culture media were assayed directly or after appropriate dilution (1:50) with fresh culture medium containing $10 \%$ FBS while the cell layers were extracted with $0.5 \mathrm{M}$ acetic acid for $18 \mathrm{~h}$ in presence of proteinase inhibitors. Cell layer extracts were neutralized before dilution (1:50) with fresh culture medium containing $10 \%$ FBS so that all values fell within the standard curve. Samples $(100 \mu \mathrm{l})$, were added directly to each well of the microtiter plate. The plate was then incubated for $1.5 \mathrm{~h}$ at $37^{\circ} \mathrm{C}$ to allow the tropoelastin to absorb, then washed with PBS. Tropoelastin antibody diluted in the same buffer $(1: 2,000)$ was added to the plate and incubated for $1.5 \mathrm{~h}$ at $37^{\circ} \mathrm{C}$. Preimmune rabbit serum and saline controls were included on each plate. Peroxidase-labeled GAR-HRP diluted 1:1,000 was used as the second antibody for another $1.5 \mathrm{~h}$ at $37^{\circ} \mathrm{C}$ and then the reaction was developed with diamino-benzidine. The tropoelastin content in each sample was calculated from a standard curve prepared with known concentrations of tropoelastin (1-32 ng) incubated in the same manner on the same plates. Because the amount of tropoelastin extractable from the cell layers was relatively small (6-24\% of total amount), values for both media and cell layers are combined in the results and figures.

Total protein synthesis in cultures with and without exogenous GAGs was determined after radiolabelling with $1 \mu \mathrm{Ci} / \mathrm{ml}$ of $\left[{ }^{3} \mathrm{H}\right]-$ Leucine for $3 \mathrm{~h}$. Culture media were removed and the cells scraped and pelleted. Newly synthesized proteins in media and cell layers were measured separately after precipitation with $10 \%$ TCA for 30 min at $4^{\circ} \mathrm{C}$ and scintillation counting of the precipitate, and then the values were combined.

Desmosine is a cross-linking amino acid, unique to elastin and to a large part responsible for the stability and elasticity of the molecule, so the levels of this amino acid provided us with additional information related to the degree of cross-linking and insolubility of elastin deposited by aortic SMC cultured with and without GAGs. We measured desmosines in matrices from three different Ao smooth muscle cell cultures treated for $7 \mathrm{~d}$ with CS and from non-CS-treated controls. Desmosines were analyzed by radioimmunoassay as described by King 

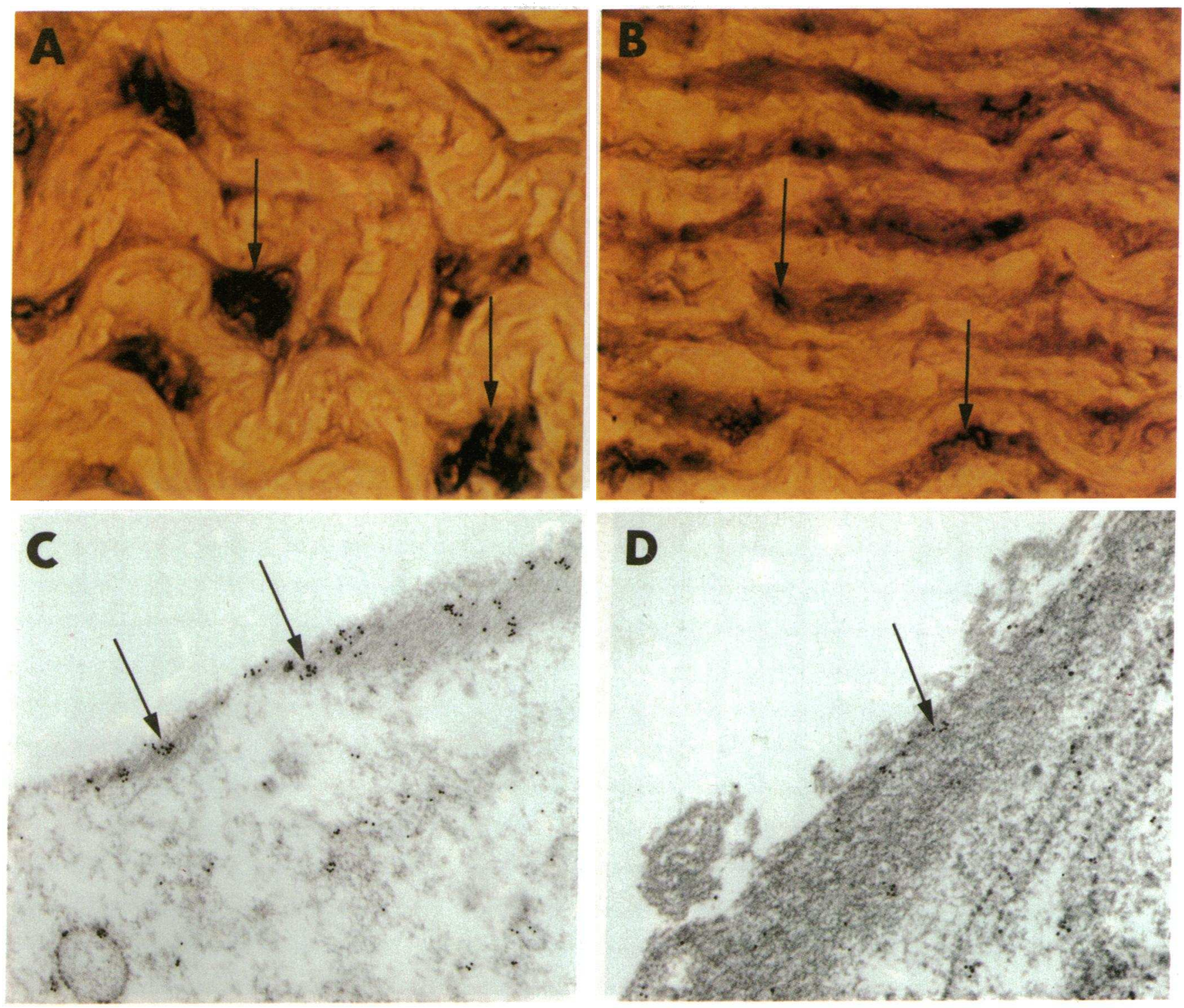

Figure 1. Immunolocalization of the 67-kD elastin binding protein using a (BCZ 67) monoclonal antibody in aorta and ductus arteriosus tissue from 138-d-gestation fetal lambs. Representative light microscopic photomicrographs of the vascular media show PAP immunolocalization of EBP over smooth muscle cells (arrows) with increased intensity of staining in aortic tissue. $(A)$ compared to ductus arteriosus $(B)$. Magnification, 400. Electron photomicrographs of immunogold localization of EBP show more antigenic sites marked with 15-nm gold particles (arrows) on the surface of a representative Ao smooth muscle cell $(C)$ than on the surface of a representative DA smooth muscle cell $(D)$. Magnification, 45,000 .

et al. (33) with triplicate determinations from each sample and values were normalized as picomoles per microgram DNA.

Data for tropoelastin and for total protein synthesis were analyzed by one-way analysis of variance and Tukey's test of multiple comparisons was used to establish which groups were different. Desmosine levels in CS and non-CS-treated cultures were compared by Student $t$ test. Statistical significance is reported with $P<0.05$.

Immunohistochemistry. Light microscopic localization of the 67kD EBP was carried out on DA and Ao paraffin embedded tissue from three different lambs using a monoclonal antibody to the $67-\mathrm{kD}$ EBP (BCZ 67) $(5 \mathrm{mg} / \mathrm{ml}$ initial concentration, diluted $1: 500)(34)$. The reaction was developed with the peroxidase anti-peroxidase (PAP) kit according to the manufacturer's instructions. For immunofluorescent localization of the 67-kD EBP in cultured cells, DA and Ao smooth muscle cells (SMC) cultured on four-well plastic slides were quickly fixed for 2 min with $0.5 \%$ paraformaldehyde (nonpermeabilized), washed in PBS, blocked with $0.5 \mathrm{M}$ glycine and $1 \%$ BSA in PBS, and incubated with the monoclonal antibody to the 67-kD EBP (BCZ 67) $(5 \mathrm{mg} / \mathrm{ml}$, diluted 1:200). The cells were then stained with fluoresceinlabeled goat anti-mouse immunoglobulin (GAM-FITC) diluted 1:100. Elastin was visualized on separate slides which were fixed in 3\% paraformaldehyde for $10 \mathrm{~min}$, then blocked with $0.5 \% \mathrm{M}$ glycine and $1 \%$ BSA in PBS, and incubated with a polyclonal anti-elastin antibody (5 $\mathrm{mg} / \mathrm{ml}$, diluted 1:200) (35), followed by rhodamine-conjugated goat anti-rabbit secondary antibody (GAR-RITC) diluted 1:100. As a control for studies using the monoclonal antibody, normal ascitic fluid was used and as a control for studies using the polyclonal antibodies, normal rabbit serum was substituted for the primary antibody. Additional controls included secondary antibody alone.

Immunoelectron microscopy. Immunolocalization of elastin and its 67-kD EBP by electron microscopy was performed by a postembedding method previously described (3). Briefly, $4 \mathrm{~mm}^{2}$ full thickness sections of Ao and DA tissue from 100- and 138-d gestation lambs or cultured cells were fixed with $0.5 \%$ glutaraldehyde and $0.5 \%$ parafor- 

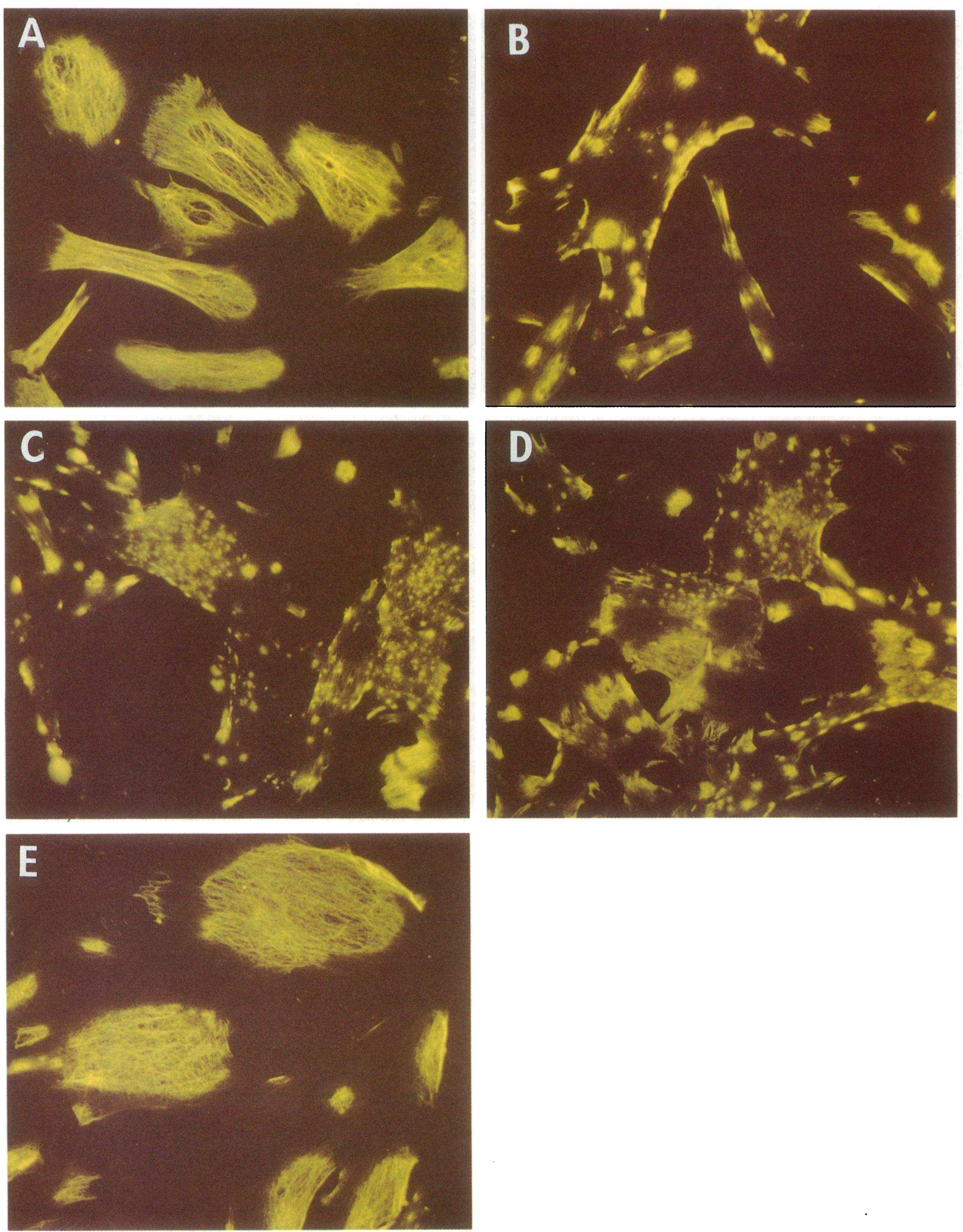
maldehyde in $0.1 \mathrm{M}$ Tris-buffered saline (TBS), $\mathrm{pH}$ 7.4. Reactive aldehydes were blocked with $0.5 \mathrm{M}$ glycine, the samples were washed with TBS, postfixed with $1 \%$ osmium tetroxide in $0.1 \mathrm{M}$ cacodylate buffer, dehydrated in ethanol, and embedded in Epon. Thin sections were placed on nickel grids, blocked with $1 \%$ BSA and $0.5 \%$ Tween 20 in TBS, and treated with polyclonal anti-elastin antibody $(5 \mathrm{mg} / \mathrm{ml}$; diluted 1:400) or with monoclonal anti-67-kD antibody (BCZ 67; diluted 1:500) washed with appropriate secondary antibodies conjugated with 15-nm gold particles. Sections were then stained with uranyl acetate and lead citrate. In all immunostaining procedures, controls included substitution of nonimmune and antigen adsorbed sera for the first antibody. To quantify differences in EBP surface antigenic sites in DA compared to Ao, 10 smooth muscle cells selected at random from each vessel were assessed. Five adjacent $1-\mu \mathrm{m}$ distances on each cell surface ( 50 per vessel) were marked off and the number of antigenic sites indicated by gold label was counted. Background counts were subtracted.

Electron microscopy. SMC cultures were also prepared for standard electron microscopic examination, i.e., fixed in $2 \%$ glutaraldehyde in $0.1 \mathrm{M}$ cacodylate buffer, postfixed with $1 \%$ osmium tetroxide in the same buffer, dehydrated in ethanol, and embedded in Spurr low viscosity resin, which assures high contrast of elastin even when thin sections are stained with uranyl acetate and lead citrate (30).

Displacement of the 67-kD EBP from elastin affinity columns by $G A G s$. The elastin affinity resin was prepared using Affi-Gel 10 and coupled by mixing $20 \mathrm{mg}$ Kappa-elastin/ml of resin according to manufacturer's directions. Active sites on resins were blocked by $0.1 \mathrm{M}$ ethanolamine, $\mathrm{pH}$ 8. As controls, plain affi-gel columns blocked with ethanolamine, and insoluble elastin affinity columns prepared without affigel or other artificial supports were also used.

To investigate the ability of CS to bind selectively to the lectin site on the 67-kD EBP and dissociate the receptor-ligand complex, plasma membranes were prepared from cultured cells as previously described (36). Membrane-bound proteins were extracted with $3 \mathrm{M}$ guanidine $\mathrm{HCl}, 10 \mathrm{mM}$ Hepes, $0.1 \mathrm{M}$ dithiotreitol (DTT), $0.5 \%$ octyl-B-glucoside (OBG) in the presence of proteinase inhibitors in the following final concentrations: $2 \mathrm{mM}$ benzamidine, $2 \mathrm{mM}$ EACA, $2 \mathrm{mM}$ PMSF, 1 $\mathrm{mM}$ EDTA, and $1 \mathrm{mg} / \mathrm{ml}$ Trasylol. Extraction was carried out overnight at $4^{\circ} \mathrm{C}$ with constant stirring and the insoluble material was pelleted by centrifugation. The supernatant was dialyzed exhaustively $\left(12,000-14,000 \mathrm{~mol}\right.$ wt cutoff membrane) at $4^{\circ} \mathrm{C}$ against $0.1 \mathrm{M}$ sodium bicarbonate, $\mathrm{pH} 8$, containing proteinase inhibitors, then mixed with elastin affinity resins and rotary shaken for $4 \mathrm{~h}$ at $4^{\circ} \mathrm{C}$. At the end of the incubation, the unbound material was removed by washing the elastin affinity resins with $0.1 \mathrm{M}$ sodium bicarbonate buffer, $\mathrm{pH} 8$, until the absorption $A_{280}$ of the eluant returned to background level. Protein bound to the elastin affinity resin was then eluted with either CS (200 $\mu \mathrm{g} / \mathrm{ml})$ or $\mathrm{HS}(200 \mu \mathrm{g} / \mathrm{ml})$ dissolved in $0.1 \mathrm{M}$ sodium bicarbonate buffer, $\mathrm{pH} 8.0$, containing $0.1 \%$ OBG. The affinity columns were subsequently washed with a solution of $100 \mathrm{mM}$ lactose and $0.1 \%$ OBG to remove any uneluted protein. All procedures were carried out at $4^{\circ} \mathrm{C}$. Proteins eluted from the affinity columns were dialyzed exhaustively against water and concentrated by lyophilization. Concentrated samples were suspended in SDS sample buffer with DTT and analyzed by SDS-PAGE on 0.45 -mm-thick $12 \%$ gels (37). Protein bands were visualized by silver staining. For western blot analysis, proteins were transferred to nitrocellulose at $100 \mathrm{~V}$ for $1 \mathrm{~h}$. The blots were incubated with monoclonal antibody to the elastin receptor (BCZ 67) diluted 1:200 and visualized using peroxidase-conjugated goat antibody against mouse immunoglobulin diluted 1:100.
Quantification of 67-kD elastin receptor subunit extracted from $D A$ and Ao cells. The relative amounts of the $67-\mathrm{kD}$ elastin receptor subunit which could be extracted from the surfaces of Ao and DA cells derived from fetal lambs was also compared by western immunoblot after treatment of the cells with lactose or chondroitin sulfate. Briefly, confluent cultures containing $10 \times 10^{6} \mathrm{SMC}$ from each vessel were incubated for $15 \mathrm{~min}$ with $5 \mathrm{ml}$ of $100 \mathrm{mM}$ lactose or chondroitin sulfate $(200 \mu \mathrm{g} / \mathrm{ml})$ in PBS. The media were collected and immediately dialyzed exhaustively at $4^{\circ} \mathrm{C}(3,500-4,000 \mathrm{~mol}$ wt cutoff membrane) against $0.1 \mathrm{M}$ sodium bicarbonate, $\mathrm{pH} 8$, containing proteinase inhibitors, and mixed with $2 \mathrm{ml}$ of elastin affinity resin for $4 \mathrm{~h}$ at $4^{\circ} \mathrm{C}$. The resins were washed as described above. All columns were then eluted using $100 \mathrm{mM}$ lactose and $0.1 \%$ OBG. Subsequent washing of the columns with the same solution failed to elute any further protein indicating that the initial elution had been complete. The eluted proteins were dialyzed, lyophilyzed, and run on SDS-PAGE. The identity of the elastin binding protein was confirmed by western blot using the $\mathrm{BCZ}$ monoclonal antibody and the amount quantified by densitometry. Parallel blots were negative using either a monoclonal antibody to BSA or a polyclonal antibody to tropoelastin (proteins of similar molecular weight).

To address the fate of EBP lost from the surfaces of SMC treated with CS or DS, we assessed relative amounts of EBP extractable both from culture media as well as from the cell layers in 3-d cultures containing $10 \times 10^{6}$ Ao SMC following the same procedures described above and using insoluble elastin affinity columns. The identity of the EBP was assessed by western blot using the $\mathrm{BCZ}$ monoclonal antibody and the amount quantified by densitometry.

\section{Results}

Distribution of the elastin binding protein in Ao and DA cells and tissue. Immunostaining of Ao and DA light microscopic tissue sections from fetal lambs localized the 67-kD EBP to the smooth muscle cells of the vessel wall. A consistent increase in intensity of immunostaining was apparent in Ao compared to DA tissue sections from all three lambs (Fig. $1 A$ and $B$ ). In tissue prepared for electron microscopy, immunogold labeling of the EBP was primarily localized to the cell surface although some intracellular staining was apparent as well. A greater number of EBP antigenic sites were labelled on Ao compared to DA cell surfaces (Fig. 1, $C$ and $D$ ). There were 20 \pm 8 (SD) EBP antigenic sites $/ \mu \mathrm{m}$ on Ao cell surfaces compared with $8 \pm 4$ (SD) EBP antigenic sites $/ \mu \mathrm{m}$ on DA cell surfaces $(P<0.0001)$. Consistent with these observations in tissue, cultured Ao cells from these lambs, when lightly fixed in the nonpermeabilized state at confluence or subconfluence, demonstrated strong fibrillar immunostaining over the entire cell surface (Fig. $2 \mathrm{~A}$ ). In contrast, cultured DA smooth muscle cells from these animals showed relatively scant, punctate, and focal distribution of immunostaining (Fig. $2 \mathrm{~B}$ ). The method of fixation made staining of intracellular components unlikely.

Influence of exogenous $G A G$ s on distribution and amounts of 67-kD EBP extractable from surfaces of Ao and DA cells. When Ao smooth muscle cells were cultured with $N$-acetylgalactosamine containing GAGs, e.g., CS or DS, the distribution of the EBP by immunofluorescence was punctate and focal,

Figure 2. Localization of the $67-\mathrm{kD}$ elastin binding protein in cultured smooth muscle cells by immunohistochemistry using fluorescein labeled secondary antibody. Cultured aortic smooth muscle cells harvested from 138-d-old fetal lambs in $A$ demonstrate fibrillar distribution of elastin binding protein over the entire cell surface, whereas cells from the ductus arteriosus in $B$ show sparse punctate perimembranous immunostaining. When fetal lamb aortic cells were cultured with chondroitin sulfate in $C$ and dermatan sulfate in $D$ the fibrillar distribution of the 67-kD elastin binding protein on the smooth muscle cell surface is lost, and sparse, punctuate immunostaining is visible instead. Cells treated with heparan sulfate in $E$ do not differ from control cells and show normal distribution of elastin binding protein on their surfaces. Magnification, 400 . 
similar to that observed on DA cells (Fig. 2, $C$ and $D$ ) and this was evident at both $2 \mathrm{~d}$ after seeding as well as at $7 \mathrm{~d}$ when the cells were fully confluent. Addition of $\mathrm{N}$-acetyl glucosaminecontaining GAGs, HS, or HA, had no effect on the strong fibrillar staining of the EBP over the entire Ao smooth muscle cell surface (Fig. $2 E$ ). When DA smooth muscle cells were incubated with either $N$-acetyl glucosamine or galactosamine containing GAGs, the punctate pattern of distribution of the EBP was not further altered.

Further studies confirmed that the 67-kD EBP could be eluted from an elastin affinity column with CS but not HS (Fig. 3 ). We then showed that the amount of EBP extractable from Ao smooth muscle cell surfaces with CS or lactose was $\sim 2.5$ times greater than the amount extractable from DA surfaces (Fig. 4). We then confirmed by densitometric analysis of western immunoblots that even after treatment with CS or DS for 3 d, a large part of the EBP lost from cell surfaces could be detected in the culture media (Fig. 5). This suggested that in the presence of galacto-GAGs, EBP lost from the cell surface stays in the medium, i.e., there is no evidence indicating major reuptake by the cells or incorporation in the matrix. In this experiment, we also showed that the 67-kD EBP could be immobilized and subsequently eluted from insoluble elastin affinity columns without any artificial support, whereas it failed to bind to affi-gel alone.

Effect of GAGs on elastin assembly in cultured cells. Immunohistochemistry of cell matrices revealed that the reduced density of the $67-\mathrm{kD}$ protein was associated with impaired assembly of elastin judged by fewer well-organized elastin fibers in DA and in Ao cells treated with CS or DS when compared to control Ao cells or Ao cells treated with HS (Fig. 6, $A-D$ ) or hyaluronan (data not shown). The lack of well-assembled elastin in the DA compared to the Ao was confirmed by immunoelectron microscopy (Fig. $7 \mathrm{~B}$ ). Well formed lamina in between Ao smooth muscle cells densely packed with immunogold label reflecting elastin antigenic sites, were unaltered by treat-

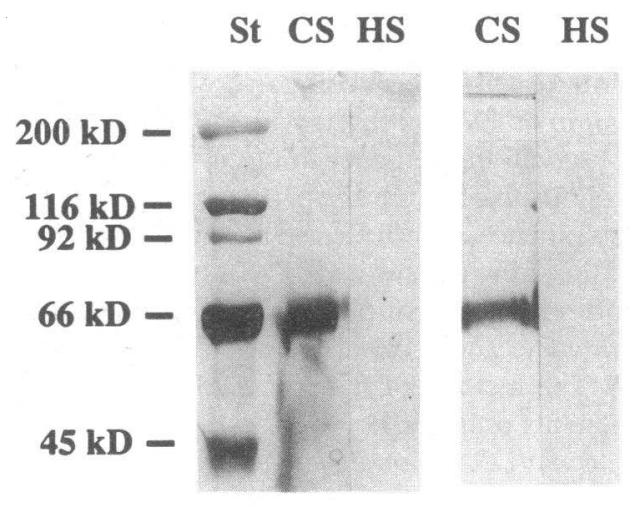

\section{SDS- PAGE Western Blot}

Figure 3. SDS-PAGE (12.5\%) silver stained and western immunoblots of $67-\mathrm{kD}$ elastin binding protein extracted from smooth muscle cell membranes passed over an elastin affinity column and eluted with GAGs. Far left shows molecular weight standards (ST): 200 kD (myosin), $116 \mathrm{kD}$ (B-galactosidase), $97 \mathrm{kD}$ (phosphorylase B), $66 \mathrm{kD}$ (BSA), $45 \mathrm{kD}$ (ovoalbumin). Chondroitin sulfate $(C S)$ but not heparan sulfate $(H S)$ eluted the $67-\mathrm{kD}$ elastin binding protein. Western immunoblot using the BCZ-67 monoclonal antibody to the $67-\mathrm{kD}$ elastin binding protein confirms the identity of the eluted protein.

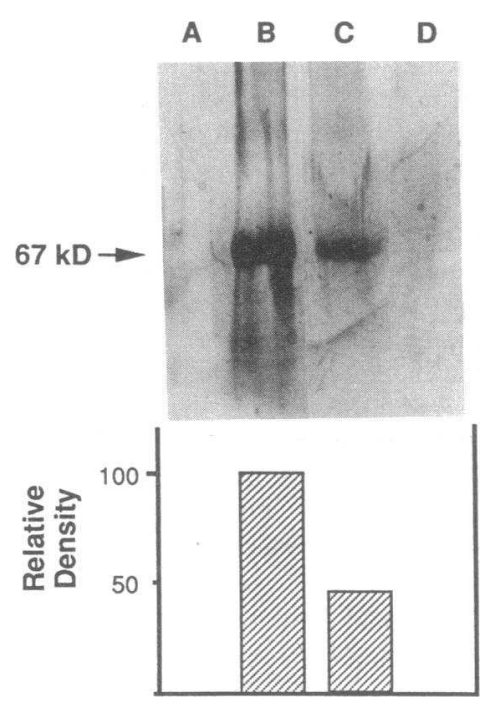

Figure 4. Densitometry of proteins resolved by SDSPAGE and immunoblotted with BCZ-67 monoclonal antibody to the $67-\mathrm{kD}$ elastin-binding protein. Proteins removed from the cell surface by chondroitin sulfate or heparan sulfate were applied to identical elastin affinity columns or plain affi-gel. Elastin binding proteins were eluted with a solution of $100 \mathrm{mM}$ lactose and $0.1 \%$ OBG in $0.1 \mathrm{M}$ bicarbonate buffer, $\mathrm{pH} 8$. No elastin binding protein extracted from Ao SMC can be absorbed and subsequently eluted from the plain affi-gel column $(A)$.

Approximately 2.5 times more of the elastin binding protein is extracted from $10 \times 10^{6}$ aortic smooth muscle cells $(B)$ as compared to the same number of cells derived ductus arteriosus $(C)$. No elastin-binding protein can be extracted from Ao SMC with heparan sulfate $(D)$.

ment with HS (Fig. $7 E$ ) or hyaluronan (data not shown). In contrast, in DA smooth muscle cells, and in Ao smooth muscle cells treated with CS or DS sparse immunogold label was scattered among a microfibrillar intercellular network, and well assembled elastin fibers were not evident (Fig. 7, $C$ and $D$ ). In

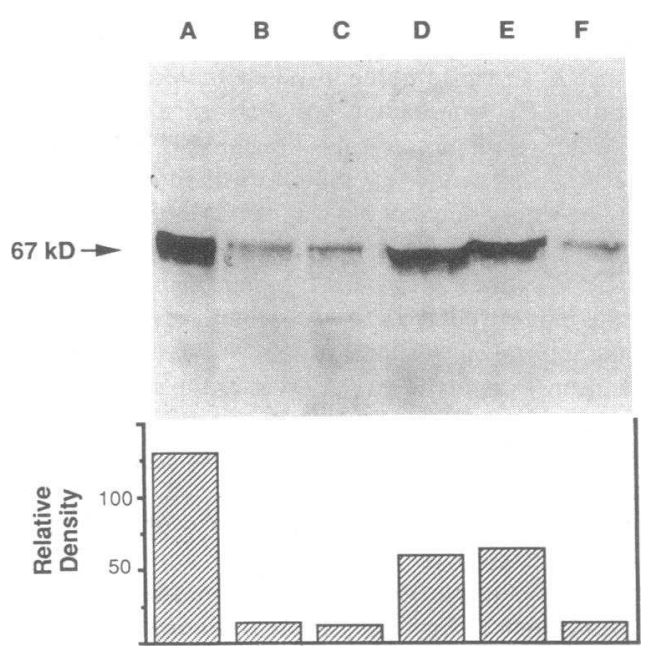

Figure 5. Western blot with BCZ-67 monoclonal antibody and densitometry of elastin-binding proteins immunoblotted. Proteins extracted from the cell layers and culture media were applied to identical insoluble elastin affinity columns. Elastin binding proteins were eluted with a solution of $100 \mathrm{mM}$ lactose and $0.1 \%$ OBG in $0.1 \mathrm{M}$ bicarbonate buffer, $\mathrm{pH} 8$, resolved on SDS-PAGE, electrotransferred to nitrocellulose, and immunoblotted. Approximately 10 times more elastin binding protein is extracted from $10 \times 10^{6}$ control aortic smooth muscle cells $(A)$ as compared to the same number of cells treated for $3 \mathrm{~d}$ with CS $(B)$ and DS $(C)$. Lanes $D-F$ show, respectively, the amounts of EBP present in the media of CS, DS, and control cultures. 

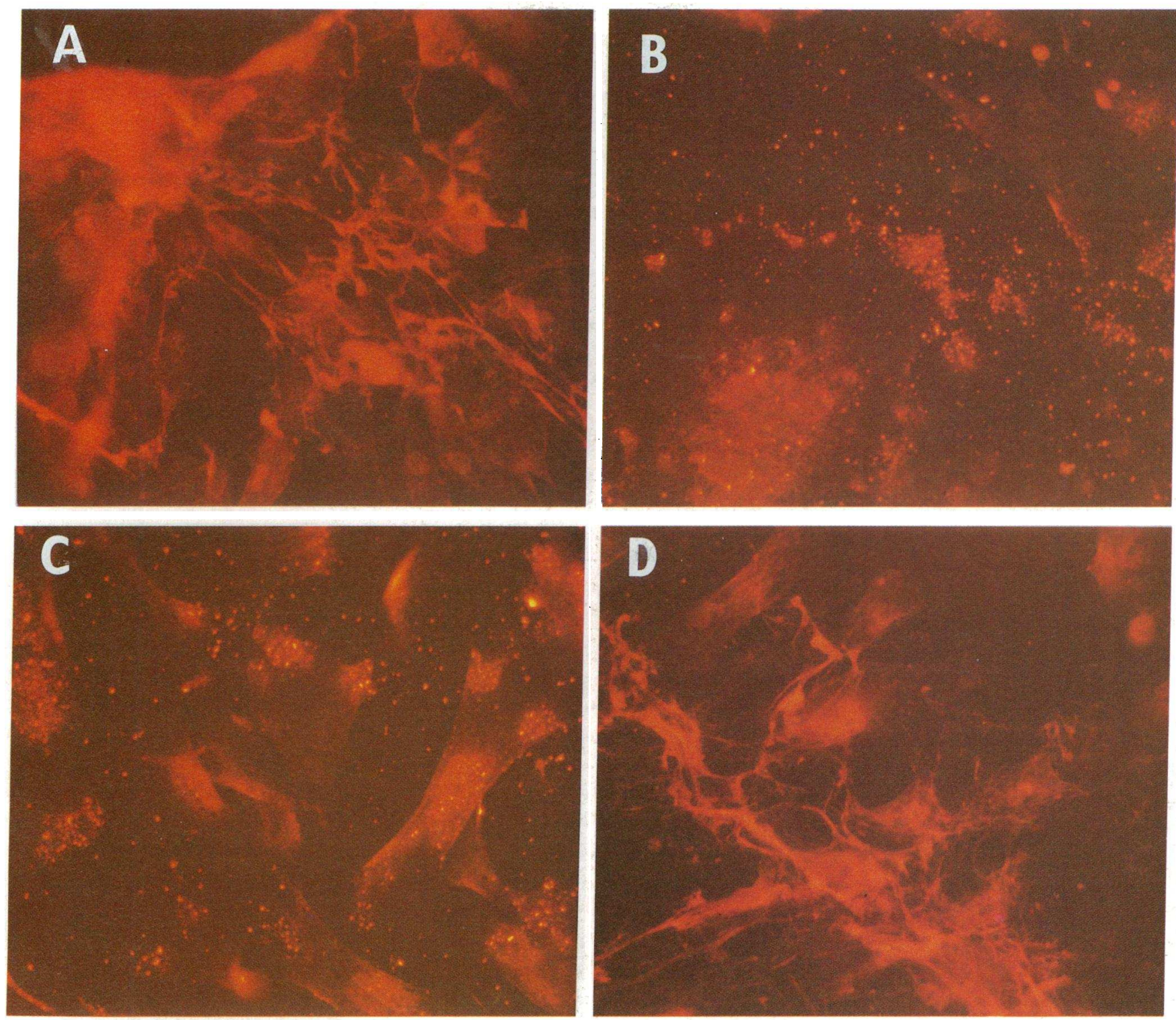

Figure 6. Immunohistochemical localization of matrix-associated elastin using a polyclonal anti-elastin antibody, and a second antibody labeled with rhodamine. 138-d-gestation fetal lamb aortic cells cultured $7 \mathrm{~d}$ under control conditions $(A)$ with chondroitin sulfate $(B)$, dermatan sulfate $(C)$, and heparan sulfate $(D)$. Elastin fibers stain in $A$ and $D$, but there is no staining of these structures evident in $B$ or $C$. Magnification, 400 .

neonatal rat aorta smooth muscle cells in culture, orderly assembly of lamina was also prevented by incubation with CS or DS (Fig. 8).

Using biochemical techniques, we also confirmed that CS and CS-treated Ao smooth muscle cells assemble elastin poorly when compared with control and HS-treated cells. This was documented by ELISA using a specific anti-tropoelastin antibody as an increase in soluble tropoelastin measured in the medium and cell layer extract over a one week period in CS and DS compared to control and HS treated cells $(P<0.001$ for all determinations) (Fig. $9 \mathrm{~A}$ ). In addition, assay of desmosines (reflecting insoluble elastin) measured by immunoassay after 7 d revealed control Ao smooth muscle cell values that were significantly higher than those from CS-treated cells $(9,858 \pm 73$ $\mathrm{pmol} / \mu \mathrm{g}$ DNA and $569 \pm 50 \mathrm{pmol} / \mu \mathrm{g}$ DNA, respectively) ( $P$ $<0.006)$. Total protein synthesis was not affected by any of these conditions (Fig. $9 \mathrm{~B}$ ) confirming that these concentrations of GAGs were not toxic to the cells.

\section{Discussion}

Impaired assembly of elastin in the DA is associated with smooth muscle cell migration and proliferation in the subendothelial space (intimal thickening), a feature which occurs in late gestation and assures that the vessel will close when it constricts postnatally. Congenital patency of the DA is associated with normal assembly of elastin and lack of intimal cushion formation (8). In this study we have addressed the mechanism of impaired elastin assembly in the DA.

We observed a reduction in the 67-kD EBP in DA compared with Ao tissue judged by immunoperoxidase staining and confirmed by immunogold labeling as fewer antigenic sites 

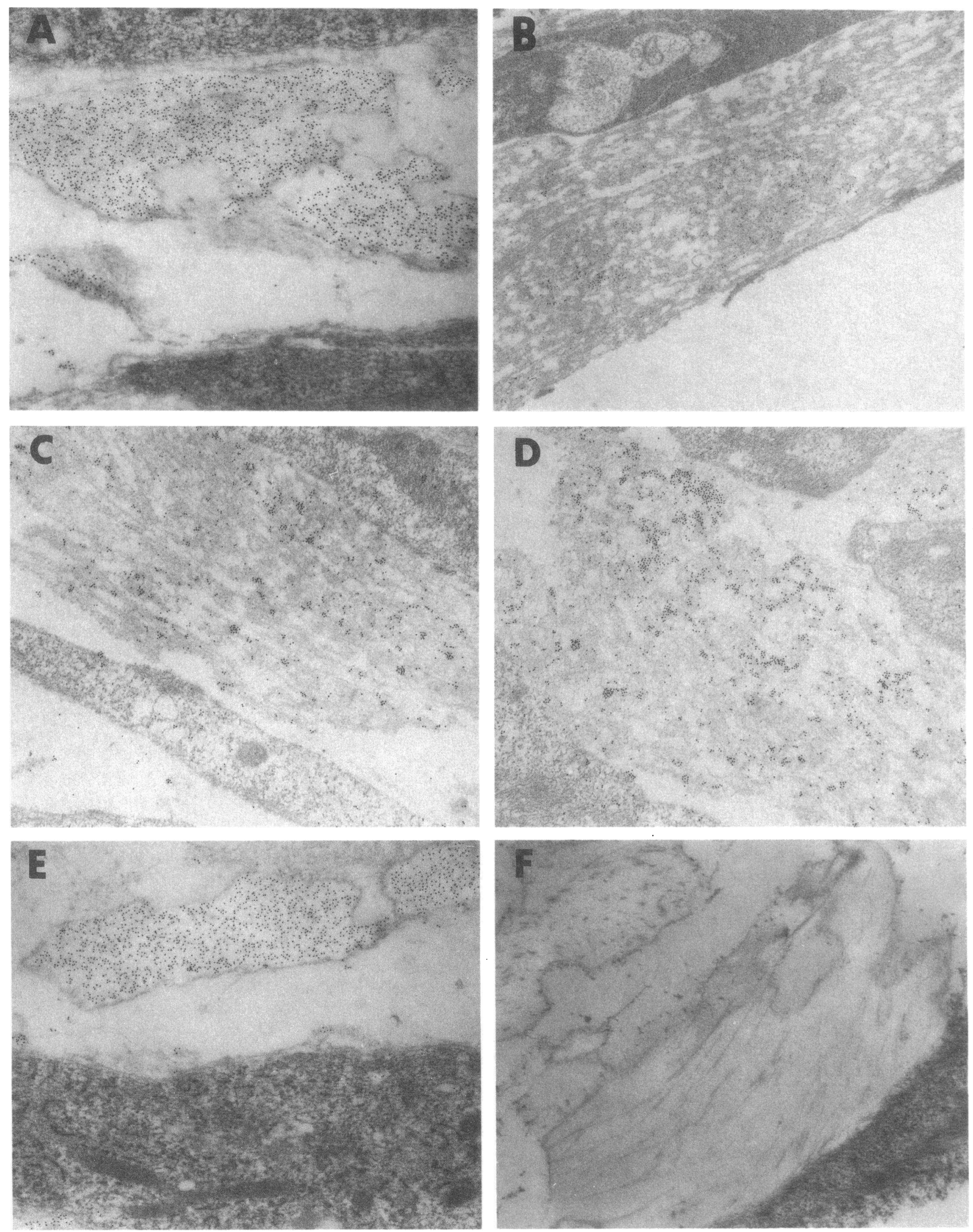

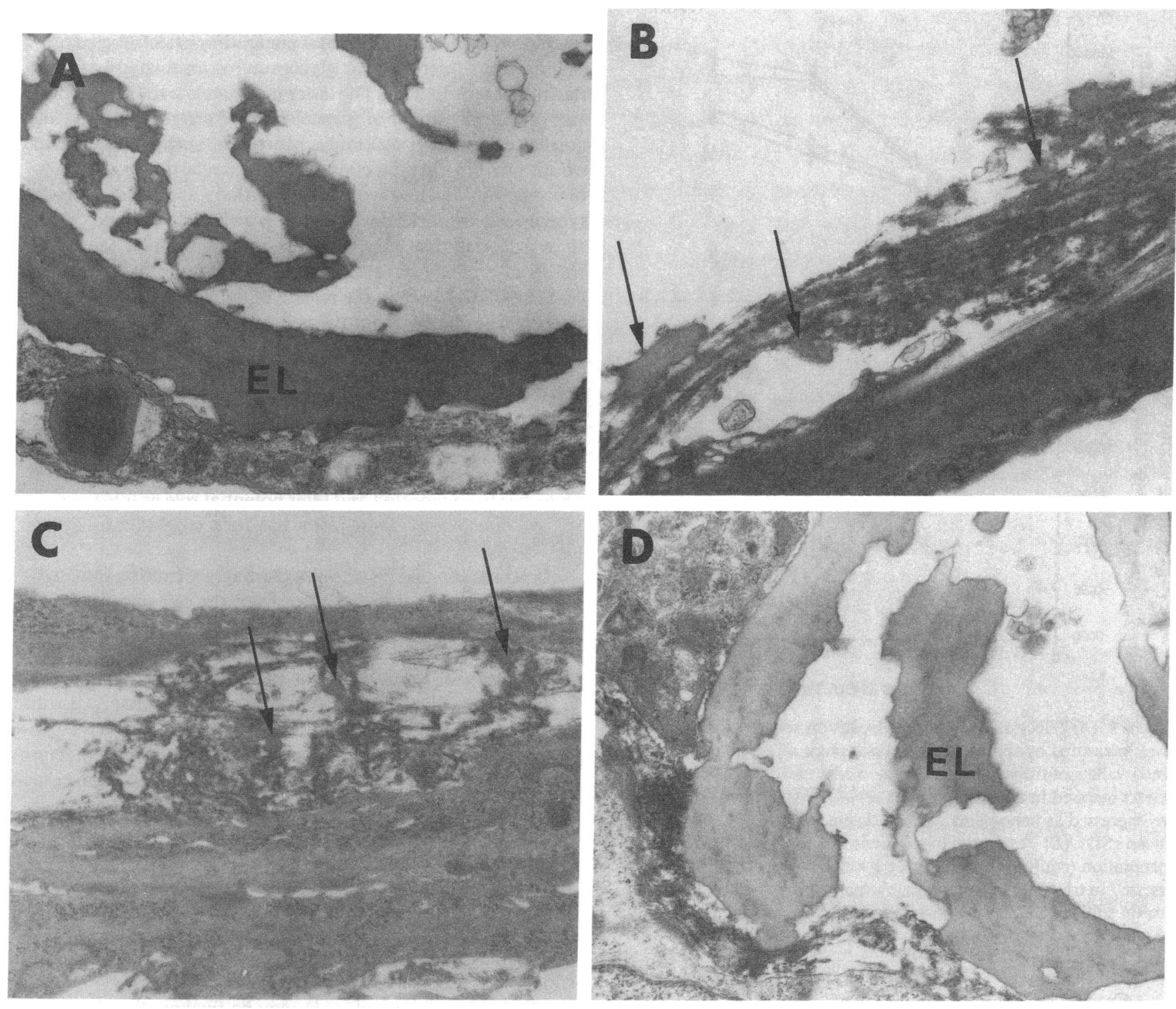

Figure 8. Representative electron photomicrographs showing the effect of glycosaminoglycans on elastin assembly in 7-d-old cultures of neonatal rat aortic smooth muscle cells. Control rat cells $(A)$ similar to control aortic lamb cells, show assembly of elastin $(E L)$ in laminae. Chondroitin sulfate $(B)$ and dermatan sulfate $(C)$ but not heparan sulfate $(D)$ cause impaired elastin fiber assembly as small particles (arrows) among the microfibrils. Magnification, 45,000.

(Fig. 1). The reduction in EBP was manifest also in cultured DA cells as sparse punctate immunofluorescent staining compared with the homogeneous fibrillar appearance in Ao cells (Fig. 2, $A$ and $B$ ). These morphologic features correlated with biochemical studies in which less EBP was extracted from DA compared with Ao cell surfaces (Fig. 4). Also, we confirmed in cultured DA cells that decreased EBP was associated with impaired assembly of elastin (Fig. 7). The DA contains a higher concentration of $\mathrm{CS}$, a galactosamine-containing GAG, than the Ao $(10,11)$ and previously we reported that assembly of elastin fibers in cell culture was impaired in the presence of lactose, galactose, and galactosamine because these compounds detach the EBP from cell surfaces (3). We therefore investigated the effects of galactosamine containing GAGs on both the distribution of the EBP on Ao smooth muscle cell surfaces and on the assembly of elastin fibers in cell culture.

Figure 7. Representative electron photomicrographs showing immunolocalization of elastin in the matrix of 7-d-old cultures of aortic smooth muscle cells derived from 138-d-gestation fetal lambs. Thin sections were treated with polyclonal anti-elastin antibody and distribution of elastin was visualized with the second antibody conjugated with 5-nm gold particles. In $A$, elastin produced by cultured aortic smooth muscle cells is assembled into lamina which stain densely with gold label, whereas elastin secreted by ductus arteriosus cells in $B$, is scattered loosely among microfibrils (mf). In the cultures of aortic smooth muscle cells treated with chondroitin sulfate in $C$ and dermatan sulfate in $D$, elastin is also distributed loosely among the microfibrils while heparan sulfate treated cultures in $E$ show dense staining over well-assembled laminalike structures. $F$ shows the control when the normal rabbit serum was substituted for the first antibody. Magnification, 45,000 . 

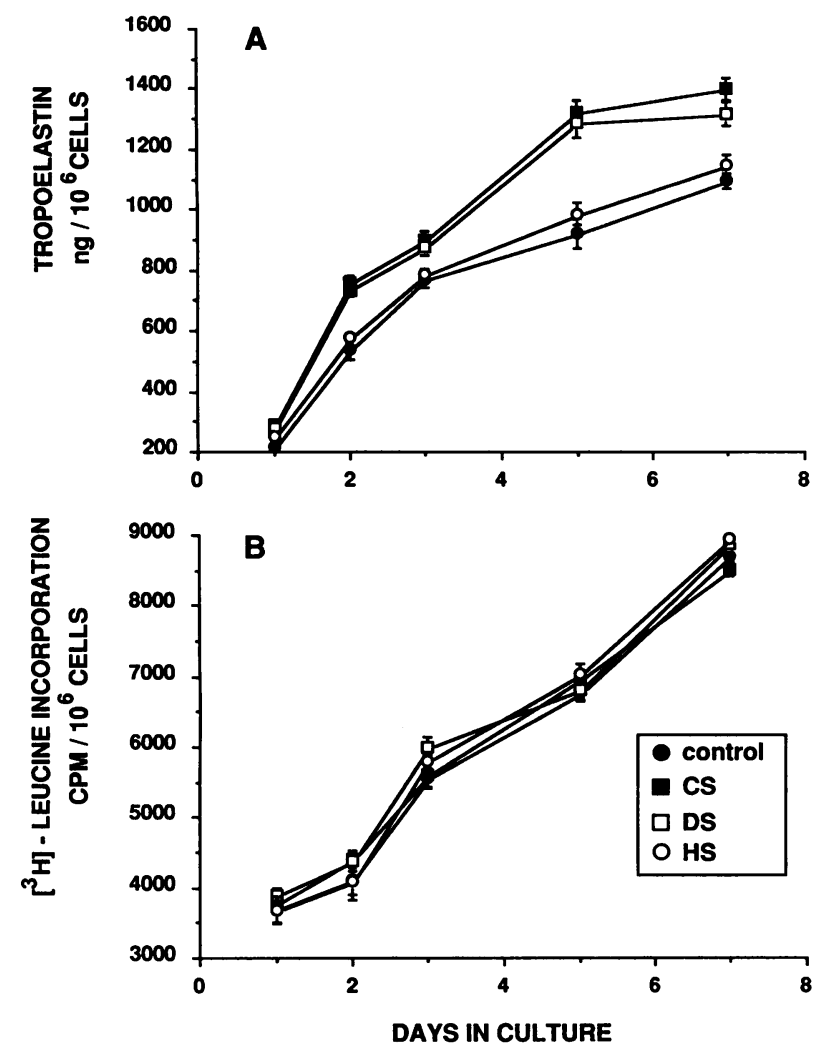

Figure 9. (A) Effect of glycosaminoglycans on soluble tropoelastin levels measured by specific ELISA. Each point represents the combined values of tropoelastin from the media and from the cell layer extract assessed in triplicate in three separate experiments. Results are expressed as nanograms of tropoelastin per $1 \times 10^{6}$ cells $($ mean $\pm S D)$. (B) Total protein synthesis measured by $\left[{ }^{3} \mathrm{H}\right]$-leucine incorporation (counts per minute per $1 \times 10^{6}$ cells, mean $\pm \mathrm{SD}$ ) was assessed in triplicate in two separate experiments. Control, CS (chondroitin sulfate); $D S$ (dermatan sulfate); $H S$ (heparan sulfate).

Incubation of fetal lamb Ao smooth muscle cells with galactosamine-containing GAGs (CS and DS) but not glucosamine containing GAGs (HS or hyaluronan) reduced the amount of EBP on cell surfaces, judged by immunohistochemistry as loss of the homogeneous fibrillar network of EBP and the presence of sparse punctate staining as observed in DA cells (Fig. 2). Moreover, removal of the EBP from the surfaces of Ao smooth muscle cells with CS or DS and its release into the medium (Fig. 5) was associated impaired elastin assembly assessed biochemically by increased tropoelastin (Fig. $9 A$ ) and reduced desmosines as well as morphologically (Figs. 6 and 7). In studies with neonatal rat aorta smooth muscle cells results were similar indicating that the response observed was not species specific (Fig. 8). While these studies do not directly prove that impaired assembly of elastin in the DA is the result of increased detachment of the EBP caused by the increased accumulation of CS, our data support this as a possible mechanism.

Because $N$-acetyl galactosamine-containing GAGs impair elastin assembly in whole tissue and in cell culture not by reducing synthesis of soluble tropoelastin or proteins in general, but by removing the EBP from the cell surface, binding of elastin to the cell surface appears to be an important step in the process of elastin fiber assembly (Fig. 10). We have previously speculated that normal release of tropoelastin from the $67-\mathrm{kD}$ receptor subunit occurs after it is engaged by galactosugars protruding from microfibrillar glycoproteins associated with the elastin fiber scaffold (4). The latter may regulate the orientation and proper alignment of tropoelastin for cross-linking during normal elastin fiber assembly. Moreover, such a mechanism would provide for protection of the tropoelastin from premature cross-linking and would allow orderly accretion of newly synthesized tropoelastin onto the growing elastin fiber. This study suggests that galacto-sugars immobilized in the GAG chains of proteoglycans can also bind to the lectin site on the $67-\mathrm{kD}$ EBP resulting in the release of bound elastin and in the dissociation of EBP from the cell membrane. We did in fact show that CS but not HS can release the 67-kD EBP bound to elastin affinity columns. Thus, the presence of high concentrations of galactosamine-containing GAGs in the matrix could interfere with the orderly assembly of elastin by untimely release of tropoelastin from the elastin-binding protein. The close spatial relationship between various proteoglycans and elastin fibers has been reported and their potential role as inhibitors of spontaneous elastin aggregation has been suggested by others $(39,40)$.

It is possible that galacto-GAGs may, by causing nonenzymatic "shedding" of the receptor from the cell surface, play a role in the natural process of elastin fiber assembly in vascular and connective tissue by limiting the size of elastin fibers and elastic laminae. An untimely or excessive increase in galactoGAGs during development may, however, completely disrupt the normal pattern of elastin fiber assembly as we have proposed in the DA, because we could detect no increase in elastase activity and no reduction in tropoelastin production (9) or in lysyl oxidase activity (our unpublished observations) to explain this feature.

Shedding of the $67-\mathrm{kD}$ receptor from the cell surface may cause uncoupling of smooth muscle cells from the surrounding matrix and may even promote their migration and may be part of the complex mechanism leading to intimal thickening in the DA. The increased migration of DA smooth muscle cells associated with fibronectin $(41,42)$ secreted in increased amounts by ductus arteriosus cells (11) may be further stimulated and directed through chemotaxis or haptotaxis by the local accumulation of nonassembled elastin (43).

It has been speculated that CS- and DS-proteoglycans destabilize focal cellular adhesions (44) by sterically interfering with binding of glycoproteins to specific cell surface receptors or by changing the configuration of the matrix glycoproteins causing a decrease in their association constant for the various receptors (45). We speculate that these compounds may also promote cell migration by effects related to shedding of the EBP described above.

Disruption of vascular elastic laminae associated with impaired assembly of newly synthesized elastin has been reported in systemic hypertension (15), atherosclerosis (46), and in pulmonary hypertension (16, and Todorovich-Hunter, L., $\mathbf{H}$. Dodo, L. McCready, F. W. Keeley, and M. Rabinovitch, submitted for publication). This feature is associated with migration of smooth muscle cells into the subendothelial space and subsequent intimal proliferation. An increase in medial GAGs has been reported in pulmonary vascular disease (16) and increased chondroitin and dermatan sulfate specifically have been reported in atherosclerosis $(21,25,47)$. Thus, through the mechanism suggested above, it is possible that these GAGs 


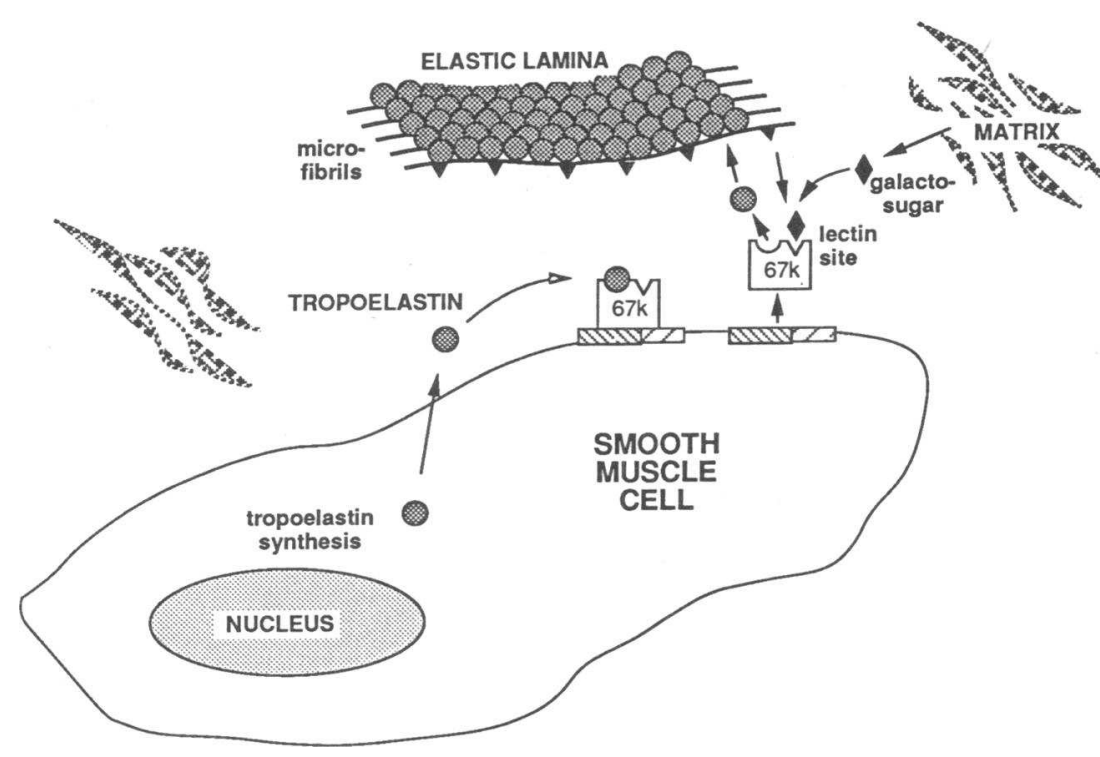

Figure 10. A schema suggesting the mechanism of elastin fiber assembly. The assembly process is mediated at the cell surface by an elastin binding complex consisting of three proteins. Two integral membrane proteins (hatched bars) form a transmembrane link between the extracellular compartment and the cytoskeleton. The third subunit is a "detachable" $67-\mathrm{kD}$ elastin-binding protein that also has galactolectin properties. It binds elastin, one of the cell membrane subunits, and galactosugars via three separate sites. Binding of galactosugars to the lectin site of the $67-\mathrm{kD}$ protein lowers the affinity for both the elastin and for the cell binding site, resulting in the release of bound elastin and the dissociation of $67-\mathrm{kD}$ subunit from the cell membrane. Coordinated binding of galactosugar-containing glycoproteins of the microfibrillar scaffold to the $67-\mathrm{kD}$ subunit with subsequent release of tropoelastin may be important in the normal assembly of the elastin fiber, whereas excess galactosugars from matrix components may "compete" and lead to abnormal assembly. may have a previously unappreciated influence on the assembly of elastic laminae and on the mechanism of intimal thickening both in disease as well as in development.

\section{Acknowledgments}

This work was supported by a grant from the Medical Research Council of Canada, MT 8546. M. Rabinovitch is a Career Investigator of the Heart and Stroke Foundation of Ontario.

\section{References}

1. Cleary, E. G., and M. A. Gibson. 1983. Elastin associated microfibrils and microfibrillar proteins. Int. Rev. Connect. Tissue Res. 10:97-209.

2. Prosser, I. W., and R. P. Mecham. 1988. Regulation of extracellular matrix accumulation: a short review of elastin biosynthesis. In Self-Assembling Architecture. J. E. Varner, editor. Alan R. Liss, Inc., New York. 1-23.

3. Hinek, A., D. S. Wrenn, R. P. Mecham, and S. H. Barondes. 1988. The elastin receptor: a galactoside-binding protein. Science (Wash. DC). 239:15391541 .

4. Hinek, A., and R. P. Mecham. 1990. Characterization and functional properties of elastin receptor. In Elastin-Chemical and Biological Aspects. A. M. Tamburro and J. M. Davidson, editors. Gelatina Congedo Editore, Maratea, Italy. 369-381.

5. Mecham, R. P., A. Hinek, R. Entwistle, D. S. Wrenn, G. L. Griffin, and R. M. Senior. 1989. Elastin binds to a multifunctional $67-\mathrm{kD}$ peripheral membrane protein. Biochemistry. 28:3716-3722.

6. Mecham, R. P., A. Hinek, G. L. Griffin, R. M. Senior, and L. R. Liotta. 1989. 67-kD elastin binding protein is homologous to the tumor cell 67-kD laminin receptor. J. Biol. Chem. 264:16652-16657.

7. Hinek, A., J. Kawiak, E. Czarnowska, and B. Barcew. 1984. Effect of agarose and dexamethasone on the nature and production of extracellular matrix components by elastic cartilage chondrocytes. Acta Biol. Acad. Sci. Hung. 35:245-258.

8. Patterson, D. F. 1979. Genetic factors in persistence of the ductus arterio sus. In Pediatric Cardiology 2: Heart Disease in the Newborn. M. J. Godman and M. Marquis, editors. Churchill Livingstone, Edinburgh.

9. Zhu, L., and M. Rabinovitch. 1990. Elastin synthesis and assembly is impaired in the fetal lamb ductus arteriosus. J. Cell Biol. 3:462a. (Abstr.)

10. De Reeder, E. G. 1989. Maturation of the ductus arteriosus. A model for intimal thickening. Ph.D. thesis. University of Leiden, The Netherlands.

11. Boudreau, N., and M. Rabinovitch. 1991. Developmentally regulated changes in extracellular matrix precede intimal proliferation in the ductus arteriosus. Lab. Invest. 64:187-199.

12. Gittenberger-deGroot, A. C., L. Van Ertbruggen, A. J. M. Moulaert, and F. Harink. 1980. The ductus arteriosus in the preterm infant. Histologic and clinical observations. J. Pediatr. 96:88-93.
13. Gittenberger-deGroot, A. C., J. L. M. Strengers, M. Mentink, R. E. Poelmann, and D. F. Patterson. 1985. Histologic studies on normal and persistent ductus arteriosus in the dog. J. Am. Coll. Cardiol. 6:394-404.

14. Yoder, M. J., F. G. Baumann, N. M. Grover-Johnson, I. Brick, and A. M. Imparato. 1978. A morphological study of early cellular changes in the closure of the rabbit ductus arteriosus. Anat. Rec. 192:19-39.

15. Wolinsky, H. 1970. Response of the rat aortic media to hypertension. Circ. Res. 26:507-522.

16. Todorovich-Hunter, L., D. J. Johnson, P. Ranger, F. W. Keeley, and M. Rabinovitch. 1988. Altered elastin and collagen synthesis associated with progressive pulmonary hypertension induced by monocrotaline: a biochemical and ultrastructural study. Lab. Invest. 58:184-195.

17. Benitz, W. E., and M. Bernfield. 1990. Endothelial cell proteoglycans: possible mediators of vascular response to injury. Am. J. Resp. Cell. Mol. Biol. 2:407-408.

18. Berenson, G. S., B. Radhakrishnamurthy, S. R. Srinivasan, P. Vijayagopal, and E. J. Dalferes. 1988. Arterial wall injury and proteoglycan changes in atherosclerosis. Arch. Pathol. Lab. Med. 112:1002-1010.

19. Merriles, M. J., and L. J. Scott. 1985. Effects of endothelial removal and regeneration on smooth muscle glycosaminoglycan synthesis and growth in rat carotid artery in organ culture. Lab. Invest. 52:409-419.

20. Berenson, G. S., B. Rahakrishnamurthy, S. R. Srinivasan, P. Viryagopal, and E. J. Dalferes. 1985. Proteoglycans and potential mechanism related to atherosclerosis. Ann. NY Acad. Sci. 3:69-78.

21. Wagner, W. D. 1985. Proteoglycan structure and function as related to atherosclerosis. Ann. NY Acad. Sci. 3:52-68.

22. Robbins, R. A., W. D. Wagner, L. M. Sawyer, and B. Caterson. 1989. Immunolocalization of proteoglycan types in aortas of pigeons with spontaneous or diet-induced atherosclerosis. Am. J. Pathol. 134.3:615-626.

23. Wight, T. N. 1980. Vessels proteoglycans and thrombogenesis. Prog. Hemostasis Thromb. 5:1-39.

24. Wight, T. N., K. D. Kurwen, M. M. Litrenta, D. R. Alonso, and C. R. Minnick. 1983. Effect of endothelium on glycosaminoglycan accumulation in injured rabbit aorta. Am. J. Pathol. 113:156. (Abstr.)

25. Wight, T. N. 1985. Proteoglycans in pathological conditions. Atherosclerosis. Fed. Proc. 44:381-385.

26. Wight, T. N., M. W. Lark, and M. G. Kinsella. 1987. Blood vessel proteoglycans. In Biology of Proteoglycans. T. N. Wight and R. P. Mecham, editors Academic Press, Orlando, FL. 267-300.

27. Wight, T. N. 1989. Cell biology of arterial proteoglycans. Atherosclerosis. 9:1-20.

28. Rabinovitch, M., T. Bothwell, S. Beharry, and G. Jackowski. 1988. Qualitative and quantitative differences in protein synthesis comparing fetal lamb ductus arteriosus endothelium and smooth muscle with cells from adjacent vascular sites. Dev. Biol. 130:250-258.

29. Ross, R. 1971. The smooth muscle cell. II. Growth of smooth muscle in culture and formation of elastic fibres. J. Cell Biol. 50:172-186.

30. Hinek, A., J. Thyberg, and U. Friberg. 1976. Heterotopic transplantation of isolated aortic cells, an electron microscopical study. Cell Tissue Res. 172:5979. 
31. Tsukada, T., D. Tippens, G. Gordon, R. Ross, and A. Gown. 1987. HH35-a muscle actin specific monoclonal antibody I: immunocytochemical and biochemical characterization. Am. J. Pathol. 126:51-60.

32. Prosser, I. W., L. A. Whitehouse, W. C. Parks, A. Hinek, P. W. Park, and R. P. Mecham. 1990. Polyclonal antibodies to tropoelastin and the specific detection and measurement of tropoelastin in vitro. Conn. Tissue Res. 25:265-279.

33. King, G. S., V. S. Mohan, and B. C. Starcher. 1980. Radioimmunoassay for desmosine. Conn. Tissue Res. 7:263-267.

34. Mecham, R. P., A. Hinek, E. G. Cleary, U. Kucich, and J. Rosenbloom. 1988. Development of immunoreagents to ciliary zonules that react with protein components of elastic fibers microfibrils and with elastin producing cells. Biochem. Biophys. Res. Commun. 151:822-826.

35. Mecham, R. P., and G. Lange. 1982. Antibodies to insoluble and solubilized elastin. Methods Enzymol. 82:744-759.

36. Wrenn, D. S., A. Hinek, and R. P. Mecham. 1988. Kinetics of receptormediated binding of tropoelastin to ligament fibroblasts. J. Biol. Chem. 263:2280-2284.

37. Laemmli, U. K. 1970. Cleavage of structural proteins during the assembly of the head of bacteriophage $T_{4}$. Nature (Lond.). 227:680-685.

38. De Reeder, E. G., N. Girard, J. C. Munsteren, D. F. Patterson, and A. C. Gittenberger-de-Groot. 1988. Hyaluronic acid accumulation and endothelial detachment in intimal thickening of the vessel wall. The normal and genetically defective ductus arteriosus. Am. J. Pathol. 132:574-585.

39. Baccarani-Contri, M., C. Fornieri, and I. Pasquali-Ronchetti. 1985. Elastin-proteoglycans association revealed by cytochemical methods. Conn. Tissue Res. 13:237-249.
40. Fornieri, C., M. Baccarani-Contri, D. Quaglino, Jr., and I. Pasquali-Ronchetti. 1987. Lysyl oxidase activity and elastin glycosaminoglycan interaction in growing chick and rat aortas. J. Cell Biol. 105:1463-1469.

41. Lacovara, J., J. B. Cramer, and J. P. Quisley. 1984. Fibronectin enhancement of directed migration of B-16 melanoma cells. Cancer Res. 44:1657-1663.

42. Boudreau, N., E. Turley, and M. Rabinovitch. 1991. Fibronectin, hyaluronan and a hyaluronan binding protein contribute to increased migration of ductus arteriosus smooth muscle cells. Dev. Biol. 143:1-13.

43. Senior, R. M., G. Griffin, R. P. Mecham, D. S. Wrenn, K. U. Prasad, and D. W. Urry. 1984. Val-Gly-Val-Ala-Pro-Gly, a repeating peptide in elastin is chemotactic for fibroblasts and monocytes. J. Cell Biol. 99:870-874.

44. Culp, L. A., J. Leterra, M. W. Lark, R. J. Beyth, and S. L. Tobey. 1986. Heparan sulfate proteoglycans as mediators of some adhesive responses and cytoskeletal reorganization of cells on fibronectin matrices: independent versus cooperative functions. In Functions of the Proteoglycans. Ciba Found. Symp. 124:1580-1583.

45. Osterlund, E., I. Eronen, K. Osterlund, and M. Vuento. 1985. Secondary structure of human plasma fibronectin: conformational change induced by calf alveolar heparan sulfates. Biochemistry. 24:2661-2667.

46. Ross, R. 1986. The pathogenesis of atherosclerosis: an update. $N$. Engl. J. Med. 314:488-500.

47. Wagner, W. D., T. E. Hardingham, and I. Edwards. 1983. Decreased amount and size of artery chondroitin sulfate proteoglycan-hyaluronic acid aggregate in atherosclerosis. Atherosclerosis. 3:47.1a. (Abstr.) 